\title{
Water Quality Evaluation of Kromoleo Swamp Tourist Area using Phytoplankton and Periphyton as Bioindicators in the Sumberpucung Sub-District, Malang, Indonesia
}

\author{
Nudia Mella Pratikasari", Endang Arisoesilaningsih, Catur Retnaningdyah \\ Department of Biology, Faculty of Mathematics and Natural Science, University of Brawijaya, Malang, Indonesia
}

\begin{abstract}
Kromoleo swamp located in Sumberpucung Malang is used as tourism, fishing, agricultural and fisheries area. The aim of this study was to evaluate the water quality in Kromoleo Swamp based on physical, chemical and biological parameters (phytoplankton and periphyton). Water biotic and abiotic factors were taken at upstream, middle 1 (left and right sides), middle 2 (left and right sides), and downstream (left and right sides). Measurements of water chemical and physics quality included temperature, brightness, solar intensity, turbidity, conductivity, pH, DO, nitrate, orthophosphate, and BOD content, as well as determined by phytoplankton and periphyton as bioindicators. TDI index (Trophic Diatom Index) was used to determine trophic status. Meanwhile, \%PTV (Pollution Tolerant Value) was used to determine the level of organic pollution. The results of this study indicated the parameters of water temperature, $\mathrm{pH}$, DO, nitrate and conductivity were still in normal levels, while BOD, turbidity, orthophosphate and water brightness reflected high organic matter pollution. Water quality based on the Shannon-Wiener diversity index of phytoplankton and periphyton was classified as clean water $\left(\mathrm{H}^{\prime}=3.3-4.3\right)$. However, aquatic trophic status based on TDI index value on phytoplankton and periphyton $(69.10-86.71)$ were categorized as eutrophic to hyper eutrophic water. While the pollution level based on \% PTV in phytoplankton and periphyton ( 27.62 - 66.88\%) grouped into lightly - heavy organic polluted.
\end{abstract}

Keywords: Periphyton, Phytoplankton, Swamp, Tourism, Water Quality.

\section{INTRODUCTION}

Malang is a regency in East Java that has diverse tourism potential with its natural beauty. Kromoleo swamp and its spring have a tourist attraction that is managed by Senggreng village located in the Sumberpucung sub-district, Malang Regency. Kromoleo swamp has high potential natural resources to develop floating restaurants, water sports, and fishing ponds. This potential may improve local community economics.

The development of tourism activities in the Kromoleo swamp increased. Unfortunately, the positive benefits followed by negative impacts. If the water quality is poor and or polluted, it may produce an unpleasant smell and unsafety for visiting tourists. The water conditions used for tourism was concerned by society, because good quality and clean water conditions are important for sustainable tourism destinations.

The survey results showed that the activities of the surrounding community who often use swamps with various activities such as intensive

\footnotetext{
* Correspondence address: Nudia Mella Pratikasari

Email : nudiamellap@gmail.com

Address : Dept. Biology, Universitas Brawijaya, Veteran Malang, Malang 65145.
}

farming, fishing, bathing, washing, and tourist attractions change the aquatic ecosystem. Therefore protection of swamps is urgently needed by monitoring water quality. Its monitoring can be done by measurements of physical, chemical and as well as aquatic biota parameters as bioindicators.

Aquatic bioindicators are used to assess the health and integrity of ecosystem. The study of organisms in disturbed ecosystems will provide important information on changes in water quality, which are usually recorded based on existing species and abundance, as well as their presence or absence of patterns of distribution [1].

Phytoplankton is highly recommended as a bioindicator of water because it has a variety of spatial and temporal distributions [2]. Water quality can be determined by using periphyton as a bioindicator. It is due to its high reproduction rate and a very short life cycle. Thus, it is expected to reflect the impact of water quality changes [3].

Based on the background above, this study aimed to evaluate the water quality of Kromoleo swamp used as a tourist attraction. To improve tourism competitiveness of existing ecosystems, the development of nature-based tourism requires the sustainability concept, integrated by the conservation concern. Measurement of 
water quality includes the water physical and chemical and biotic indices analyzed using the TDI index (Trophic Diatom Index) and \%PTV (Pollutant Tolerant Value) as bioindicators.

\section{RESEARCH METHODS}

\section{Study area}

The study was conducted on January 2018 April 2019 in the Sumberpucung Sub-District, Malang Regency at ordinate $08^{\circ} 09^{\prime} 35.8^{\prime \prime} \mathrm{S}$ and $112^{\circ} 30^{\prime} 44.6^{\prime \prime} \mathrm{E}$ to $08^{\circ} 09^{\prime} 51.2^{\prime \prime} \mathrm{S}$ and $112^{\circ} 30^{\prime} 34.6^{\prime \prime}$ E. It is located in the upstream, middle 1 (left and right sides), middle 2 (left and right sides), and downstream (left and right sides) stations (Fig. 1). The water, periphyton, and phytoplankton were sampled. Physical and chemical water parameters, periphyton, and phytoplankton density were measured and analyzed in the Ecology Laboratory, Department of Biology, Faculty of Mathematics and Natural Sciences, University of Brawijaya Malang.

\section{Determination of Physical and Chemical Water Quality}

Physical and chemical water parameters were measured. Water temperature measured with a thermometer, brightness with Secchi disk, the solar intensity with a lux meter. We also use $\mathrm{pH}$ meter, DO meter, conductivity meter, and turbidity meter. Orthophosphate was measured by using the molybdate method and BOD using potentiometry [4].

\section{Phytoplankton and Periphyton Sampling}

Phytoplankton samples were taken in the same sites with water physical and chemical measurements. We took 1 liter of water samples using a water sampler in depth of 3-5 meters and then filtered using a plankton net, then put into a flacon bottle with 10 drops of $4 \%$ formalin and 5 drops of $\mathrm{CuSO}_{4}$. Whereas for periphyton observation held by using artificial substrate $(5 \mathrm{x}$ $5 \mathrm{~cm}$ ).

The substrate with buoys applied in the water during 2-3 weeks at each station, so the substrate submerged in the water as periphyton growing media. Three substrates were applied as a replication at each station. Then periphyton samples were taken by sweeping on the surface of the substrate and put in a shallow pan and filtered using on the plankton net and sprayed with water. Periphyton samples were filled in a flacon bottle and dripped with formalin and $\mathrm{CuSO}_{4}$. Periphyton and phytoplankton sampling at seven stations with three replication, so the total was 42 samples.

\section{Data analysis}

The physical and chemical water quality data were analyzed using a multiple comparison test among research stations using ANOVA by Turkey HSD (if data distribution was normal) and the Brown-Forsythe test. It then continued by the Games-Howell test (in case of the data was not homogeneous). Profile of phytoplankton and periphyton were determined based on the INP Value, Shannon-Wiener Diversity Index $\left(\mathrm{H}^{\prime}\right)$, Taxa Richness, Trophic Diatom Index (TDI) and percentage Pollution Tolerant Value (\% PTV) $[5,6]$.

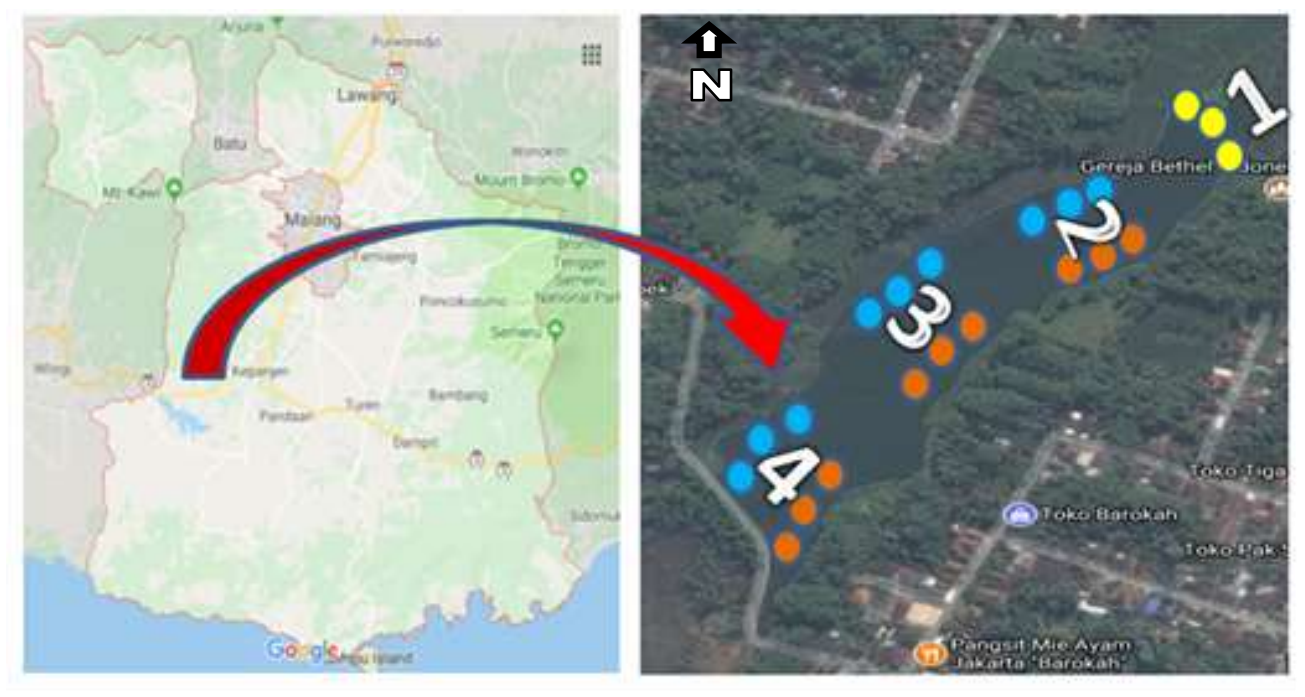

Figure1. Research location map in Kromoleo Swamp Note:* station 1 to 4 were sampling sites 


\section{RESULT AND DISCUSSION \\ Physical-Chemical Parameters}

The physical and chemical water parameters in Kromoleo swamp showed in Table 1. The water temperature ranged from $26.9^{\circ} \mathrm{C}$ to $28.4^{\circ} \mathrm{C}$. The highest water temperature located upstream (location 1) with $28.4^{\circ} \mathrm{C}$. It was because of the different time while measure-ments affect the temperature. Measurements at station 1 carried out during the day. The water surface temperature in Indonesia generally ranged from $23^{\circ} \mathrm{C}$ to $31^{\circ} \mathrm{C}$. Naturally, the surface water temperature is warmer because it gets solar radiation during the day [7]. Temperature is a limiting factor for aquatic organisms because aquatic biota is susceptible to the increase in water temperature [8].

The highest water brightness found in the middle 1 (left side) station with $67.3 \mathrm{~cm}$ and the lowest value is in an upstream station with 23 $\mathrm{cm}$. The high brightness in the middle 1 (left side) station because this site was a central area of the swamp that is open and relatively calm so that the light can be deeper entering the waters. Brightness values expressed in meters and strongly influenced by weather conditions, measurement time, turbidity, suspended solids, as well as the accuracy of the researcher. The measurements of brightness parameters should be conducted during sunny weather [9].

The highest solar intensity in Rawa Kromoleo was in the middle 1 (right side) station, its belong $131.5 \mathrm{klux}$, while for the lowest value in middle 2 (left side)22.3 Klux. Location middle 2 (right side) had the highest solar intensity value because there were no trees around the swamp while sampling, it make the sunlight easier to fill the waters. Factors that caused the difference in solar intensity are the presence of sunlight and the position (latitude-longitude) of the waters to the sun. The coming angle of sunlight depends on different times (morning or evening), even differences can occur at any time [10].

Turbidity value ranged from 6.39 to 101.63 NTU. The highest turbidity value was in the upstream and lowest in the downstream (left side) station. Turbidity indicate the brightness of the water, which is determined based on the amount of sunlight that entering the waters. High turbidity can be caused by high levels of organic and inorganic materials that dissolved and suspended into water [11].

Conductivity value in the Kromoleo Swamp ranged from $303.66-370.33 \mu \mathrm{S} . \mathrm{cm}^{-1}$. The highest conductivity value was in the upstream station and the lowest in downstream (left side) station. Conductivity comes from nitrate, phosphate, chloride, sulfate, iron, calcium, and aluminum. These ions were contained in domestic waste. Conductivity values that are too high can damage aquatic organisms [12]. A decrease in water quality disrupted aquatic organism within.

The $\mathrm{pH}$ value of Kromoleo Swamp ranged from 6.06 to 7.4. The lowest $\mathrm{pH}$ value was in downstream (left side), while the highest was in location 1 (upstream). Water $\mathrm{pH}$ stability is strongly influenced by the growth of phytoplankton, in this case, related to $\mathrm{CO}_{2}$ as an ingredient for photosynthesis. $\mathrm{pH}$ influenced by biological activities such as photosynthesis and respiration of organisms. $\mathrm{pH}$ values changes in waters can affect the growth of the biological activity of aquatic organisms [13]. Drastically increasing the acidity of the water can be due to acid rain [14].

Dissolved oxygen (DO) value ranged from $4.48 \mathrm{mg} \cdot \mathrm{L}^{-1}$ to $6.23 \mathrm{mg} \cdot \mathrm{L}^{-1}$. The highest $\mathrm{DO}$ in the upstream station, while the lowest was in downstream (left side) station. The low level of dissolved oxygen can be influenced by several factors, which can be due to organic pollution and the lack of oxygen producers [15]. Low dissolved oxygen value in an ecosystem can disrupt aquatic life [16]. It will also affect the community respiration in a water ecosystem [17].

Nitrate value in Kromoleo Swamp ranged from $0.62 \mathrm{mg} \cdot \mathrm{L}^{-1}$ to $0.77 \mathrm{mg} \cdot \mathrm{L}^{-1}$. The highest nitrate value is in the middle 1 (right side) station and lowest at downstream (left side) station. The increasing of nitrate can be due to decomposer activity and the presence of several aquatic organism wastes [18].

Orthophosphate value ranged from 1.13 $\mathrm{mg} . \mathrm{L}^{-1}$ to $1.48 \mathrm{mg} . \mathrm{L}^{-1}$. The highest orthophosphate was in the upstream station and the lowest was in downstream (left side) station. The orthophosphate value in the upstream station was higher than other stations caused by the agricultural waste flowing into the swamp; this station intersects directly with rice fields. In general, orthophosphate used for plant metabolism in the process of its growth. Therefore, human activities such as agriculture, orthophosphate parameters can be used in the growth of crops. The rest of the orthophosphate will flow to the river [19]. Orthophosphate is the limiting factor used for the growth of algae in lakes and rivers [20]. 
Post-Tin Mining Ponds Tourism in Bangka Island

(Liliani et al)

Table 1. Water Physical and Chemical Parameters in Kromoleo Swamp Sumberpucung Malang

\begin{tabular}{|c|c|c|c|c|c|c|c|c|}
\hline Parameters & $\begin{array}{c}\text { Upstre } \\
\text { am }\end{array}$ & $\begin{array}{c}\text { Middle } \\
1 \text { (L) }\end{array}$ & $\begin{array}{c}\text { Middle } 1 \\
\text { (R) }\end{array}$ & $\begin{array}{c}\text { Middle } 2 \\
\text { (L) }\end{array}$ & $\begin{array}{c}\text { Middle } 2 \\
\text { (R) }\end{array}$ & $\begin{array}{c}\text { Downstrea } \\
m(L)\end{array}$ & $\begin{array}{c}\text { Downstream } \\
(\mathrm{R})\end{array}$ & $\begin{array}{c}{ }^{*} \text { Government } \\
\text { regulation }\end{array}$ \\
\hline $\begin{array}{l}\text { Water } \\
\text { temperature }\left({ }^{\circ} \mathrm{C}\right)\end{array}$ & 28.4 & 27.36 & 28 & 27.7 & 28.2 & 26.9 & 27.6 & Deviation 3 \\
\hline Brightness $(\mathrm{cm})$ & 23 & 67.33 & 40.66 & 68 & 48 & 66.33 & 56.33 & $>400 * * * *$ \\
\hline $\begin{array}{l}\text { Sunlight intensity } \\
\text { (klux) }\end{array}$ & 63.70 & 54.80 & 131.47 & 22.33 & 82.70 & 24.63 & 767.67 & - \\
\hline Turbidity (NTU) & 101.63 & 7.69 & 9.54 & 7.72 & 7.3 & 6.39 & 7.93 & $5-30$ \\
\hline $\begin{array}{l}\text { Conductivity } \\
\left(\mu \mathrm{S} . \mathrm{cm}^{-1}\right)\end{array}$ & 370.33 & 338.33 & 351 & 331.33 & 310.67 & 303.66 & 311.66 & $0-3000 * * *$ \\
\hline $\mathrm{pH}$ & 7.4 & 6.29 & 7.03 & 6.13 & 6.52 & 6.06 & 6.09 & $6-9$ \\
\hline $\mathrm{DO}\left(\mathrm{mg} \cdot \mathrm{L}^{-1}\right)$ & 6.23 & 5.1 & 4.7 & 4.96 & 4.95 & 4.48 & 4.74 & $>4$ \\
\hline Nitrate $\left(m g \cdot \mathrm{L}^{-1}\right)$ & 0.66 & 0.72 & 0.77 & 0.67 & 0.66 & 0.62 & 0.7 & 10 \\
\hline $\begin{array}{l}\text { Orthoposphate } \\
\left(\mathrm{mg} . \mathrm{L}^{-1}\right)\end{array}$ & 1.47 & 1.13 & 1.16 & 1.12 & 1.16 & 1.13 & 1.17 & $0,04-0,16^{* *}$ \\
\hline $\mathrm{BOD}\left(\mathrm{mg} \cdot \mathrm{L}^{-1}\right)$ & 14.13 & 12.13 & 12.27 & 9.97 & 10.59 & 12.32 & 12.02 & 3 \\
\hline
\end{tabular}

The activity of decomposers in decomposing organics matter is determined by BOD value. High BOD value reflects the high organic content that can be degraded biologically. BOD value ranged from $9.97 \mathrm{mg} \cdot \mathrm{L}^{-1}$ to $14.13 \mathrm{mg} \cdot \mathrm{L}^{-1}$. In natural waters, dead plants and animals are sources of organic matter. In addition, domestic and industrial waste also affect BOD value [9].

Based on the result above, it was known physical and chemical water parameters that not qualified in standards were BOD, turbidity, orthophosphate, and water brightness. Those parameters had high value, caused by domestic waste, organic waste, and mud sedimentation through into the waters.

\section{Water Quality in Kromoleo Swamp Based on Phytoplankton}

The highest taxa richness of phytoplankton (Fig. 3) in Kromoleo Swamp was in downstream (left side) station (25), and the lowest middle 1(right side) station (18). IVI (Important Value Index) showed that each station dominated by different species. In the upstream station was dominated by Pediastrum simplex (19.60\%), Navicula gregaria (17.64\%), and Nitzchia palea (15.06\%). In middle 1 (left side) was dominated by Pediastrum simplex(17.30\%), Nitzchia palea (15.72\%), and Skeletonema (14.57\%). In middle 1 (right side) was dominated by Mastogloia (27.19\%), Navicula gregaria (23.13\%), and D. Vulgaris (19.27\%). In middle 2 (left side) was dominated by Synedra ulna (17.95\%), D. Vulgaris (17.83\%), and Achnantes (16.68\%). In middle 2 (right side) was dominated by Nitzchia filiform (17.04\%), Synedra ulna (16.15\%), and Nitzchia amphibia (15.38\%). Downstream (left side) was dominated by Nitzchia palea (13.65\%), Nitzchia filiform (13.20\%), and Nitzchia minerals(12.75\%). Downstream (right side) station was dominated by Navicula gregaria (13.69\%), Pediastrum simplex (12.89\%), and Nitzchia palea (12.09\%).

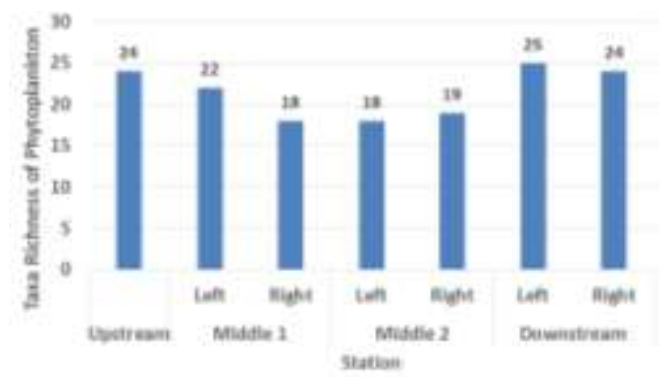

Figure 3. The Taxa Richness of Phytoplankton in Kromoleo Swamp

Based on the results of IVI analysis (Fig. 4), there were two groups of plankton which always appear in large quantities than others, Bacillariophyta and Chlorophyta. Bacillariophyta group showed the highest appearance in the waters. It caused by a high ratio of $\mathrm{N}$ and $\mathrm{P}$ values in the Kromoleo Swamp. With a high N/P ratio in water, the composition of the Bacillariophyta group plankton will increase [21]. $\mathrm{N}$ is an important nutrient to support the growth of diatom phytoplankton (Bacillariophyta) [22].

Phytoplankton Diversity Index based on Shannon-Wiener ( $\mathrm{H}^{\prime}$ ) (Fig. 5) ranged from 3.62 to 4.36. The highest was in downstream (right side) station, which means that the condition of the aquatic ecosystem at the station was good and classified in clean waters. The low diversity index value in other stations can be due to the presence of water temperature conditions and pollutants (nitrates and phosphates) [23]. 


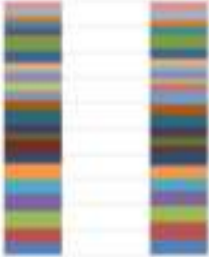

Upstream

teft

Might

teht

Might

teft

Might Station

- Pedinstrum simplex

- Nitrchio fuformit

- Smedra alna

acheasthes

" Molosiro varians

n Dactylococcopsis

- Oedogonìm

- Symechococysth

* fncyonema coesphtonom
- Nonviada gregurio

m Ulotrík

- D. Vufgoris

- Nitzchie amphiba

e Anaboeno

= Frustulla valgant

@ Achnenthidhum minotissemum

- Costeriam venis

a Tabellaria fiocrulosa
- Nitrchio pales

w Nitribia lineralh

- Mastogloia

- Skeletonemo

"Schenedesmis

Nituchle ockularis

Oscillotorio

- Merimepedia tenuissima

Figure 4. Important Value Index (IVI) of Phytoplankton in Kromoleo Swamp

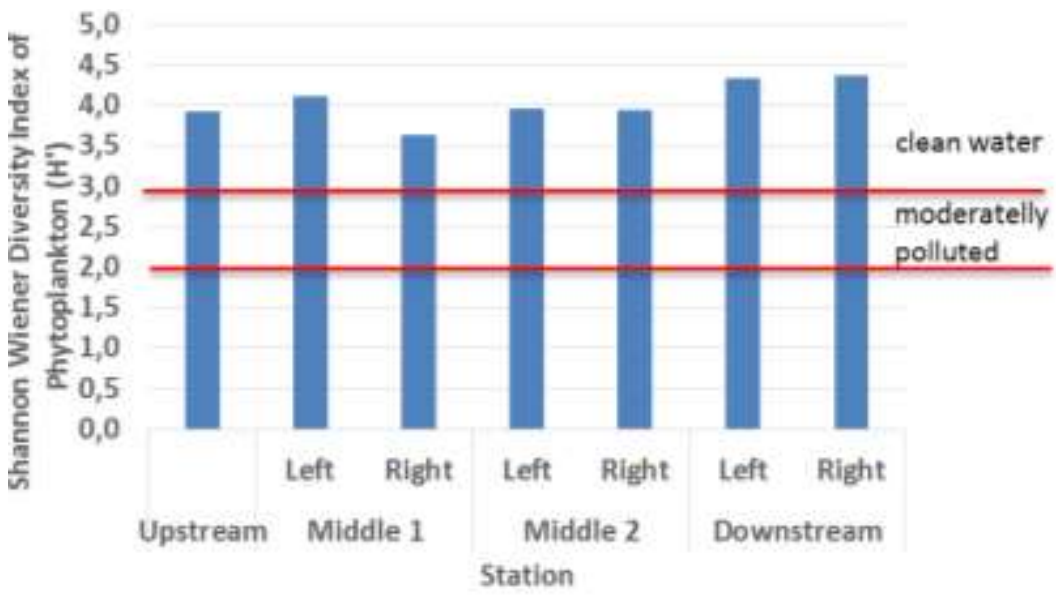

Figure5. Shannon-Wiener Diversity Index of Phytoplankton in Kromoleo Swamp

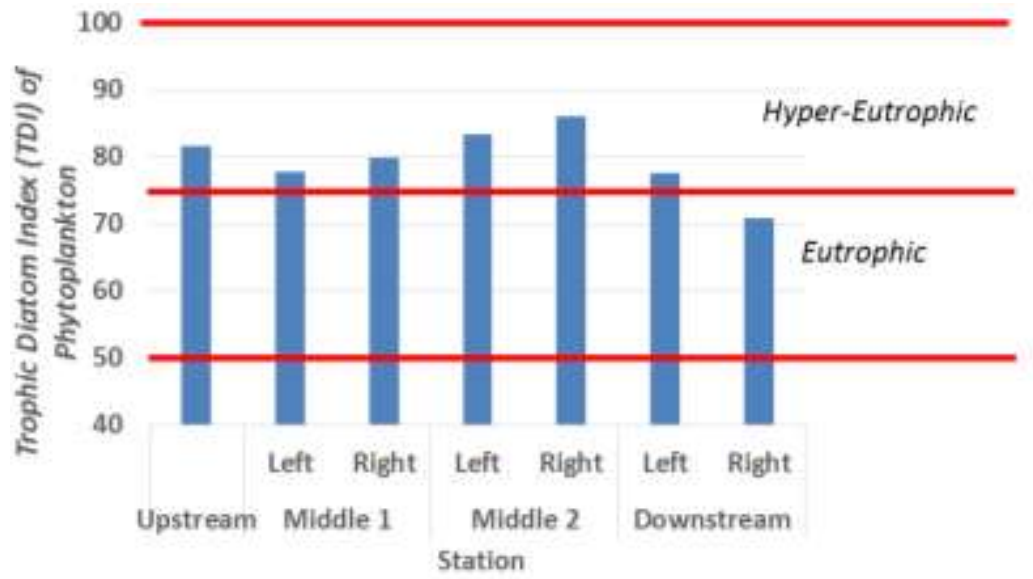

Figure 6. Trophic Diatom Index (TDI) value of phytoplankton in Kromoleo Swamp 


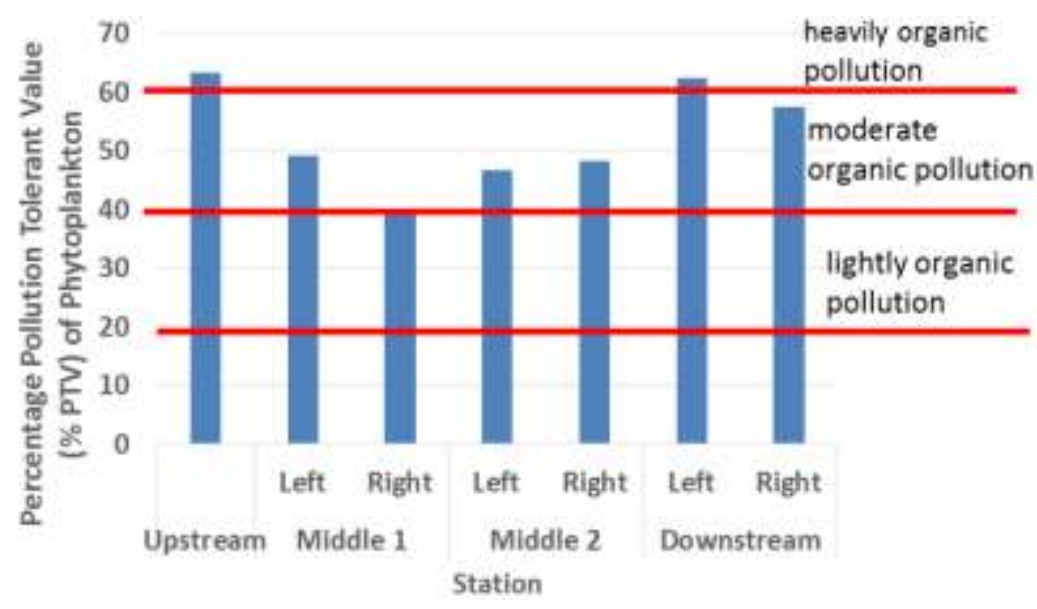

Figure 7. Percentage of Phytoplankton Pollutant Tolerant Value in Kromoleo Swamp

Trophic Diatom Index (TDI) was an index that used to determine the aquatic trophic status based on the richness and composition number of diatoms in the waters. Otherwise, the value of \%PTV (Percentage Pollution Tolerant Values) is used to analyze the condition of waters, which indicates the contamination of organic matter grouped in several classes. If the value of \%PTV is less than $20 \%$ means that the waters are free of organic pollutants, $21-40 \%$ means it polluted with light organic matter; $41-60 \%$ means it polluted with moderate organic matter, and if the value of more than $61 \%$ means it polluted by heavy organic matter [24]. TDI values can be grouped into four groups, oligo eutrophic (0-25); meso-eutrophic (25-50); eutrophic (50-75); and hyper-eutrophic (75-100) [6]. The results of TDI values on phytoplankton (Fig. 6) in Kromoleo swamp ranged from 70.85 to 85.96 and included in the eutrophic - hypereutrophic category.

The results of the \% PTV analysis on phytoplankton (Fig. 7) ranged from $39.13 \%$ to $63.33 \%$. The highest \%PTV value was in the upstream station (63.33\%), which means the water polluted by heavy organic matter. Meanwhile, the lowest \%PTV value is in the middle 1 (right side) station (39.13\%), which means contaminated with lightly organic matter. So it could be concluded that the \%PTV value of phytoplankton in Kromoleo Swamp was lightlyheavy contaminated organic pollution category.

\section{Water Quality in Kromoleo Swamp Based on Periphyton}

The highest periphyton taxa richness (Fig. 8) in Kromoleo swamp was in downstream (right side) station (22), and the lowest is in the middle 1 (left side) location (15). Important Value Index
(IVI) of periphyton in the upstream station was dominated by species between Ulothrix (18.66\%), Nitzschia palea (16.58\%), and Nitzschia acicularis (15.41\%). In middle 1 (left side) there was codominance of Synedra ulna (24.45\%), Nitzchia filiformis (22.39\%), and Navicula gregaria (20.42\%). In middle 1 (right side) station was dominated by Ulothrix (28.27\%), Scenedesmus (27.51\%), and Navicula gregaria (22.95\%). In middle 2 (left side) station was dominated between Skeletonema (31.03\%), Achnanthes (26.40\%), and Synedra ulna (22.90\%). In middle 2 (right side) there was-dominance of Achnanthes (33.69\%), Navicula gregaria (24\%), and Skeletonema (22.20\%). In downstream (left side) station there was co-dominance between Synedra ulna (18.82\%), Skeletonema (18.82\%), and Ulothrix (14.09\%). And in the downstream (right side) station there was co-dominance of Synedra ulna (16.43\%), Ulothrix (16.31\%), and Pediastrum simplex (13.93\%).

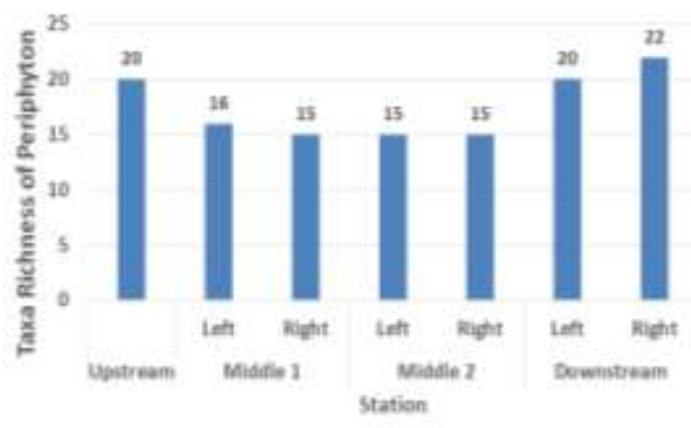

Figure 8. The Taxa Richness of Periphyton in Kromoleo Swamp

Three periphyton groups appeared in the waters based on the observation, namely Bacillariophtya, Cyanobacteria, and Chlorophyta 
groups. Whereas in the results of the Periphyton Important Value Index (IVI) analysis (Fig. 9), the two highest groups dominate, namely Bacillariophyta and Chlorophyta. Achnantes genus is the highest number of the Bacillariophyta group. Achnantes is a genus that is sensitive and tolerant against organic pollutants [6]. Whereas the highest Chlorophyta group was from Ulothrix Genus.

Periphyton Diversity index based on ShannonWiener( $\mathrm{H}^{\prime}$ ) (Fig 10) in Kromoleo swamp ranged

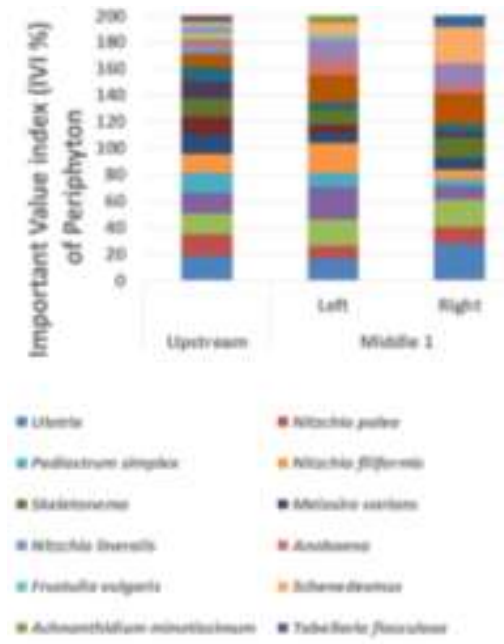

Figure 9. Important Value Index (IVI) of Periphyton in Kromoleo swamp

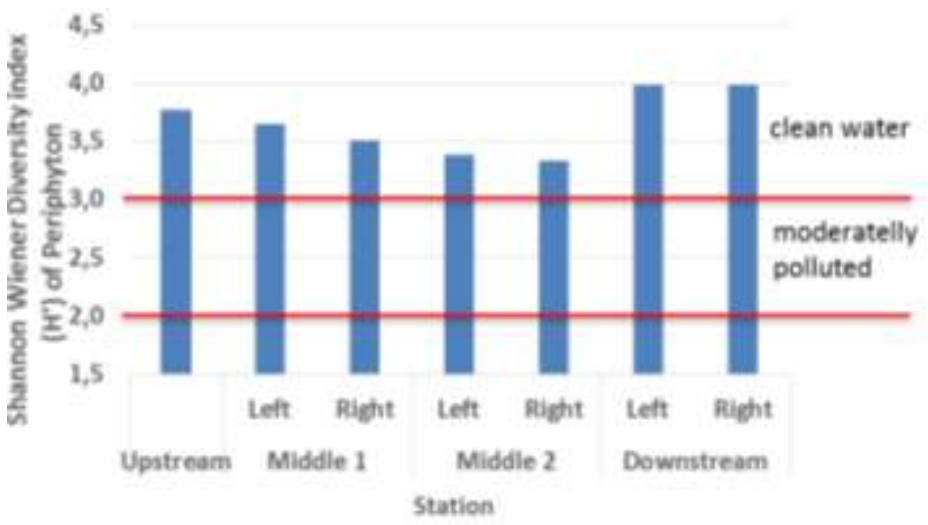

Figure 10. Shannon-Wiener Diversity Index of Periphyton in Kromoleo Swamp

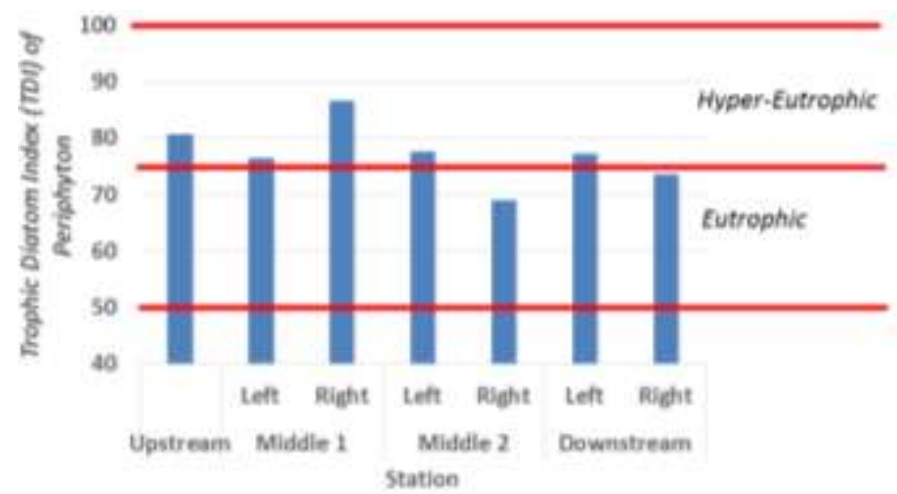

Figure 11.Trophic Diatom Index (TDI) value of Periphyton in Kromoleo Swamp from 3.33 to 3.99, the highest is in downstream(right side). It implies that the condition of the waters can characterize in clean waters.

The results of Periphyton TDI analysis (Fig. 11) showed that the tropical status of Kromoleo swamp has ranged from 69.10 to 86.71 . The highest TDI value was in the middle 1 (right side) station and the lowest in the middle 2 (right side) station, which means that TDI value can be classified as eutrophic to hypereutrophic class.
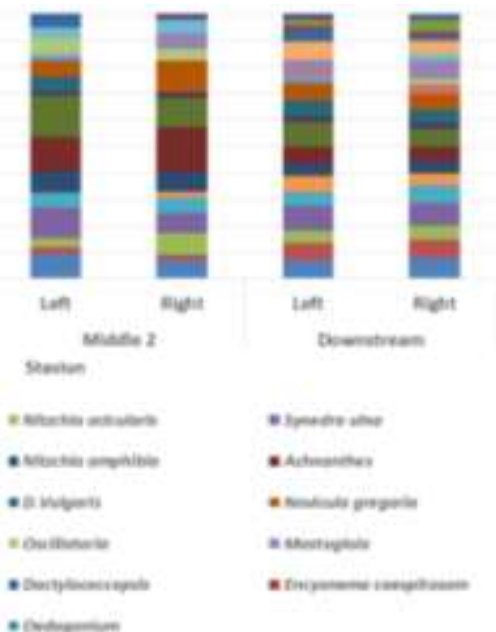


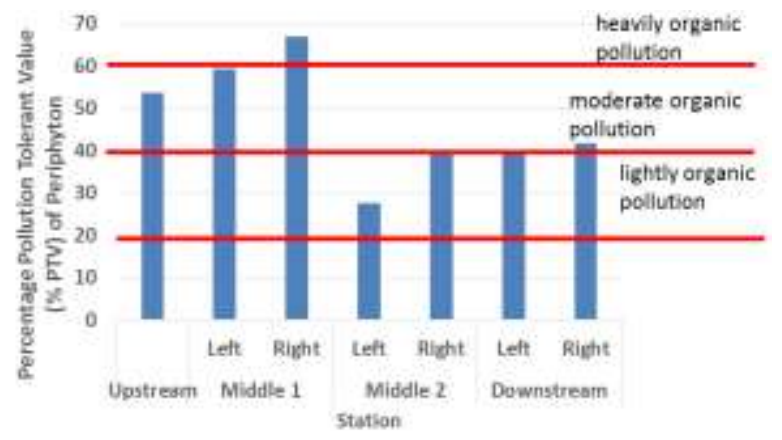

Figure 12. Percentage of Periphyton Pollutant Tolerant Value in Kromoleo swamp

The pollution level based on Periphyton \%PTV analysis (Fig. 12) in Kromoleo swamp ranged from $27.62 \%$ to $66.88 \%$. The highest value was in the middle 1 (right side) station, and the lowest was in the middle 2 (left side) station. Based on this value can classify as lightly organics polluted to heavy organics pollution. Diatoms are an organism that usually used as bioindicators to determine water quality that indicated the pollution level of organic matters [25].

Periphyton and phytoplankton will have an impact on Kromoleo swamp tourist area that has been designated as tourist centers. There are two types of aquatic organisms that have a special attraction for tourists. Based on using them as a bioindicator, tourists can appreciate about conditions in the tourist area and application of the ecological tourism concept, not only business-oriented but also regard to the environment. Tourists that focus on seeing the existing natural-tourism conditions will report, discuss, and follow up when they found a tourist spot that has a lot of pollution. Aquatic pollution in Kromoleo swamp that caused by the lack of tourism manager's attention will relate to the sustainability of tourism itself.

\section{CONCLUSION}

Water quality in Kromoleo swamp based on its phytoplankton and periphyton indicated that the water polluted by organic matter and nutrient content. It reflected by high levels of BOD, turbidity, orthophosphate, and water brightness. It exceeds the water quality standards set in all study sites, while other parameters (water temperature, $\mathrm{pH}, \mathrm{DO}$, nitrate, and conductivity) were still normal levels. Shannon Wiener diversity index categorized in clean waters, which did not indicate toxic pollution. Trophic status based on the TDI index (Tropic Diatom Index) on phytoplankton and periphyton were in eutrophic to hypereutrophic category. Last, based on the \%PTV on phytoplankton and periphyton were classified as lightly organics polluted to heavy organics pollution. The impact of high pollution can decrease tourism attraction due to bad swamp condition, like unwell smell in Kromoleo swamp which can also decrease the income of surrounding communities whose depend on their economies in Kromoleo swamp tourist area.

\section{Acknowledgment}

The author would like to thank the staff and surrounding community of Senggreng village in Sumberpucung Sub-district who provided very useful information and allowed researchers to take samples at Kromoleo Swamp. We also thanks all colleagues and staff Laboratory of the Ecology and Animal Diversity, University of Brawijaya Malang.

\section{REFERENCES}

[1] Onyema, I. C. 2013. Phytoplankton bioindicators of water quality situations in the lyagbe lagoon, South-western Nigeria. actaSATECH 4(2), 93-107.

[2] Chellappa, N., F. Camara, and Rocha. 2009. Phytoplankton community: an indicator of water quality in the Armando Ribeiro Gonçalves Reservoir and Pataxo Channel, Rio Grande de Norte, Brazil. Brazilian Journal of Biology 69(2), 241-251.

[3] Li, L., Z. Binghui, and L. Lusan. 2010. Biomonitoring and bioindicators used for river ecosystems: definitions, approaches, and trends. Procedia Environmental Sciences, 1510-1524.

[4] Clesceri, L. S., A. E. Greenberg, and A. D. Eaton. 1998. Standard methods for the examination of water and wastewater $20^{\text {th }}$ edition. American Public Health Association. Washington D.C.

[5] Jorgensen, S. E., R. Costanza, and F. Xu. 2005. Ecological indicators for assesment of ecosystem health. Taylor and Francis Group. CRC Press. USA

[6] Kelly, M. G., C. Adams, A. C. Graves, J. Jamieson, J. Krokowski, E. B. Lycett, J. M. 
Bligh, S. Pritchard, and C. Wilkins. 2001. The trophic diatom index: A user's manual. Revised edition. Environment Agency. Bristol.

[7] Nontji, A. 2005. Laut Nusantara (Marine Nusantara). Djambatan. Jakarta, Indonesia.

[8] Prasetyo, H. D. and C. Retnaningdyah. 2013. Peningkatan kualitas air irigasi akibat penanaman vegetasi riparian dari hidromakrofita lokal selama 50 Hari. Biotropika 1, 149-153.

[9] Effendi, H. 2003. Telaah Kualitas Air. Kanisius. Yogyakarta.

[10] Kwon H. K., S. J. Oh, and H. S. Yang. 2013. Growth and uptake kinetics of nitrate and phosphat by benthic microalga for phytoremediation of eutrophic coastal sediments. Bioresource Technology 129, 387-395.

[11] Faza, M. F. 2012. Struktur komunitas plankton di Sungai Pesanggrahan dari bagian hulu (Bogor, Jawa Barat) hingga bagian hilir (Kembang, DKI Jakarta). Universitas Indonesia Press. Jakarta.

[12] Morrison, G., O. S. Fatoki, L. Persson, and A. Ekberg. 2001. Assesment of the impact of poinr source pollution from the Keiskammahoek sewage treatment plant on the Keiskamma river - $\mathrm{pH}$, electrical conductivity, oxyge -demanding substance (COD) and nutrients. Water SA 27(4), 475480.

[13] Weirich, C. A. and T. R. Miller. 2014. Freshwater harmful algal blooms: toxins and children's health. Current Problem Pediatric Adolescent Health Care 44(1), 224.

[14] Oram, P. B. 2014. Watershed assessment, education, training, and realtime water quality monitoring. Available at: http://www.water-research.net/index.php/ watershed.

[15] McCoy, W. F. and B. H. Olson. 1986. Relationship among turbidity, particle counts and bacteriological quality within water distribution lines. Water Research 20(8), 1023-1029.

[16] Mandaville, S. M. 2002. Benthic macroinvertebrates in taxa tolerance values, metrics, and protocols. Project $\mathrm{H}-1$, Soil and Water Conservation Society of Metro Halifax 5, 48-120.

[17] Caraco, N. F. and J J. Cole. 2002. Contrasting impacts of a native and alien macrophyte on dissolved oxygen in a large river. Ecological Applications 12(5), 1496-1509.

[18] World Health Organization (WHO). 2011. Nitrate and nitrite in drinking water: WHO guidelines for drinking water quality. WHO.

[19] Beaty, T. A. 2015. Life on the Mississippi: Reducing the harmful effects of agricultural runoff in the Mississippi River Basin. Ohio NUL Rev. 41, 819-965.

[20] Lu, J., H. Wu, and M. Chen. 2011. Effects of nitrogen and phosphorus on phytoplankton composition and biomass in 15 subtropical, urban shallow lakes in Wuhan, China. Limnologica 41, 48-56.

[21] Pratiwi, N. T. M., S. Hariyadi, I. P. Ayu, A. Iswantari, and J. F. Amalia. 2013. Komposisi fitoplankton dan status kesuburan perairan Danau Lido, Bogor-Jawa Barat melalui beberapa pendekatan. Jurnal Biologi Indonesia 9(1), 111-120.

[22] Gilpin, L. C., K. Davidson 2004. The influence of changes in nitrogen: silicon ratios on diatom growth dynamics. Journal of Sea Research 51, 21-35.

[23] Dallas, H. F. 2008. Water temperature and riverine ecosystems: An overview of knowledge and approaches for assessing biotic responses, with special reference to South Africa. Water SA 34(3), 393-404.

[24] Schmalz, N. and N. Fohrer. 2014. Study progress in riverine phytoplankton and its use as bio-indicator - a review. Austin Journal of Hydrology 1(1), id1003.

[25] Retnaningdyah, C. and E. Arisoesilaningsih. 2018. Using benthic diatom to assess thesuccess of batch culture system phytoremediation process of water irrigation. Journal of Tropical Life Science 8(3), 259-268

[26] Retnaningdyah, C., E. Arisoesilaningsih, and S. Setijono. 2017. Use of local hydromacrophytes as phytoremediation agent in pond to improve irrigation water quality evaluated by diatom biotic indices. Biodiversitas 18(1), 1611-1617.

[27] Ayers, R. S. and D. W. Westcoc. 1985. Water quality for agriculture, irrigation and drainage. Paper No. 29 (Rev. 1). FAO. Rome.

[28] Carlson, R. E. and J. Simpson. 1996. A coordinator's guide to volunteer lake monitoring methods. North American Lake Management Society. 